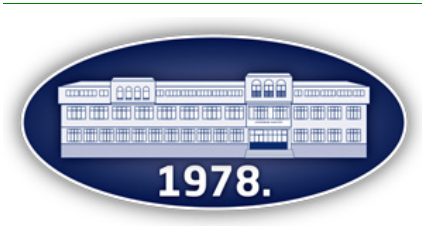

\title{
Suitability of leached soils of Western Serbia for potato growing
}

\author{
Marijana Dugalić1, Goran Dugalić ${ }^{2}$, Ljiljana Bošković-Rakočević2 ${ }^{*}$, Zoran Dinić ${ }^{3}$, \\ Anita Todorović ${ }^{2}$ \\ ${ }^{1}$ University of Niš, Faculty of Agriculture, Kosančićeva 4, 37000 Kruševac, Serbia \\ 2 University of Kragujevac, Faculty of Agronomy, Department of Soil and Mechanisation, Cara Dušana 34, 32000 Čačak, \\ Serbia \\ ${ }^{3}$ Institute of Soil Science, Teodora Drajzera 7, 11000 Belgrade, Serbia \\ *Corresponding author: ljiljabr@kg.ac.rs
}

Received 12 July 2021; Accepted 30 November 2021

\begin{abstract}
A B S T RA C T
Potato can be grown on a large number of soil types. In order to determine the suitability of leached soils for potato growing in Western Serbia, a trial was set up with the aim of observing agrophysical and agrochemical properties of this type of soil in the region of the Radočelo mountain massif in 2020. Three soil profiles were opened. Results pointed out that leached soils of Western Serbia are suitable for potato growing according to their agrophysical properties, but unfavourable as regards some agrochemical parameters (a low content of available phosphorus, high values of active, exchangeable, and hydrolytic acidity). Nevertheless, it is possible to achieve high yields that approach the biological potential of potato using appropriate soil amendment practices (timely application of proper amounts of the complex NPK fertiliser with increased phosphorus and potassium levels, basal liming of the soil along with manuring, and use of physiologically neutral nitrogen fertilisers).

Keywords: leached soil, potato, agrophysical properties, agrochemical properties.

\section{И 3 В О Д}

Кромпир се може гајити на већем броју типова земљишта, па је у циљу утврђивања погодности лесивираних земљишта за гајење кромпира на подручју Западне Србије постављен оглед са испитивањем агрофизичких и агрохемијских особина овог типа земљишта. Оглед је постављен током 2020. године на подручју планинског масива Радочело, где су отворена три педолошка профила. Добијени резултати указују да су лесивирана земљишта Западне Србије по агрофизичким особинама погодна за гајење кромпира, док су агрохемијске особине у појединим параметрима незадовољавајуће (низак садржај приступачног фосфора, високе вредности активне, супституционе и хидролитичке киселости), али уз адекватну поправку истих (примену адекватне и правовремене количине комплексног NPK ђубрива са повећаним садржајем фосфора и калијума, калцизације земљишта заједно са хумизацијом и азотних ђубрива са физиолошки неутралном реакцијом), могуће је остварити високе приносе који се приближавају његовом биолошком потенцијалу за принос.
\end{abstract}

Кључне речи: лесивирано земљиште, кромпир, агрофизичке особине, агрохемијске особине.

\section{Introduction}

Luvisols or leached soils belong to the group of automorphic soils, and to the class of eluvial-illuvial soils with the A-E-B-C profile. According to the international system of soil classification (World Reference Base for Soil Resources - WRB), this type of soil is defined as Albisol or Albeluvisol. These soils are characterised by prolonged clay migration/leaching from the surface layers of soils into deeper layers, as well as by $\mathrm{CaCO}_{3}$ leaching (dealkalisation), which results in the formation of the eluvial $\mathrm{E}$ and illuvial B horizons, which are rich in phyllosilicates. Therefore, typical luvisols have an A-E-Bt-C or A-E-Bt-(B)-C profile structure unless the process of gleysation is present (Dugalić and Gajić, 2012).

Physical properties of luvisols are non-uniform and depend on regions in which these soils are present, as well as on the parent material. According to KapovićSolomun and Eremija (2017) and Tomić et al. (2011), there are two subtypes of leached soils depending on the parent material on which they have developed: 1) luvisols formed on silicate or silicate-calcareous substrate and 2) luvisols formed on limestone or dolomite. Correspondingly, physical and chemical properties also differ. However, Dugalić and Gajić (2012) further classified luvisols in the following subtypes taking into account the direction of their additional development: typical leached soils, pseudogleyic soils and podzolic leached soils. A humus accumulative Ah horizon is most often sandy-loam (Đorđević et al., 2011), i.e. coarse to medium silty loam (Dugalić and Gajić, 2012). Unlike the surface Ah horizon, the Bt horizon is richer in clay by 1.5 times (Đorđević et al., 2011), and therefore it is of a heavier soil texture (heavy loam to clay). If a process of pseudo- 
gleysation occurs and if upper groundwater is formed above the $\mathrm{Bt}$ horizon, then it is designated as $\mathrm{Bg}$ horizon (Kapović-Solomun and Eremija, 2017). Water and air properties of typical luvisols vary, and they are significantly poorer in the Bt horizon, but, unlike pseudogley luvisols, they are characterised by relatively good water permeability, and there is no formation of upper groundwater. As found by Đorđević et al. (2011), water capacity is medium, as is the aeration of the Ah horizon. Water capacity is the highest in the eluvial horizon, 15-20 vol\% (Driessen et al., 2001).

Chemical properties of these soils are quite nonuniform and unfavourable, depending on the parental material and weather conditions. The active acidity of the surface horizon varies from $\mathrm{pH} 5.5$ to $\mathrm{pH} 6$ (Đorđević et al., 2011), while the corresponding pH values range from 4.7 to 6.5 , with the acidity not exceeding 5.5 in the majority of observed soil samples (Dugalić and Gajić, 2012). The illuvial horizon (Bt) has a slightly higher pH value (6-6.5) (Đorđević et al., 2011), which is in accordance with the results obtained by Kapović-Solomun and Eremija (2017), who determined that the acidity increased at greater depths at almost all soil sampling sites. The humus content in the $\mathrm{Ah}$ horizon of leached soil significantly varies from $1 \%$ to over 8\% (Dugalić and Gajić, 2012), but it usually does not exceed 2-3\% (Kapović-Solomun and Eremija, 2017). With regard to the supply of soil base cations, Dugalić and Gajić (2012) and Kapović-Solomun and Eremija (2017) indicated that luvisol was rather poorly supplied, including high deficits of bases, especially in the humus accumulative horizon. Slightly more favourable ion adsorption capacity occurred in luvisols formed on limestone.

Potato can be grown on a number of soil types, achieving its maximum biological potential of $40 \mathrm{t} \mathrm{ha}^{-1}$ in intensive production, which points to its great adaptability (Bošković-Rakočević et al., 2018). It is generally grown on acid to slightly acid soils with $\mathrm{pH}$ 5.2-6.4. Regarding soil texture, the biological potential of potato is best expressed on coarse to medium heavy loams and coarse clays, while tuber growth and development are poorer on heavy clays, which are usually water-impermeable, and therefore the yield is lower. Skeletal soils are not suitable for potato cultivation (Mcpharlin, 2014), but potato growth is possible on sandy soils under treatments involving timely, regular irrigation and fertilisation with organic fertilisers prior to planting during primary tillage. With regard to soil moisture, the soil should be water permeable, i.e. have good filtration ability, and be well aerated.

The objective of this study was to determine the suitability of leached soils in the region of Western Serbia for potato cultivation, based on the obtained values of observed agrophysical and agrochemical properties.

\section{Materials and methods}

The samples were drawn in the region of the Radočelo mountain massif (slopes of Mount Golija $44^{\circ} 34^{\prime} \mathrm{N}, 19^{\circ} 46^{\prime} \mathrm{E}, 1100$ masl) in 2020 , in order to observe the agrophysical and agrochemical properties of leached soil. Three soil profiles were opened and samples were drawn in the following order: in the first soil profile, disturbed samples were drawn to study soil texture at the depths of $0-30 \mathrm{~cm}, 30-50 \mathrm{~cm}, 50-70 \mathrm{~cm}$ and $70-90 \mathrm{~cm}$. It was noticed that the given soil had a structure of the Ah-AE-Bt-C profile. In the second soil profile, three undisturbed soil samples were drawn in Kopecky cylinders from each soil horizon in order to determine porosity, bulk density/volume weight, specific gravity, packing density, pore pressure coefficient, as well as pore diameter. In the third soil profile, three disturbed samples were drawn for testing water and air properties of the soil at the depths of $0-30 \mathrm{~cm}, 30-50 \mathrm{~cm}$ and $50-70 \mathrm{~cm}$. Moreover, three undisturbed samples were drawn in Kopecky cylinders for testing water filtration in the horizons. In order to observe basic agrochemical properties, samples were drawn from the second soil profile at the depths of $0-25 \mathrm{~cm}, 25-40 \mathrm{~cm}, 40-60 \mathrm{~cm}$ and $60-90 \mathrm{~cm}$.

Testing of agrophysical and agrochemical properties was performed at the Institute of Soil Science in Belgrade using the following methods: for soil texture testing: the sieve method was applied for large fractions (\%) and the pipette method (sedimentation in stagnant water) for small fractions (\%), while filtration $\left(\mathrm{cms}^{-1}\right)$ was determined by the water column constant pressure laboratory method. The following laboratory methods were used to determine agrochemical properties: the Kotzman method for the humus content; potentiometric method for active $\left(\mathrm{pH}_{2} \mathrm{O}\right)$ and exchangeable $\left(\mathrm{pH}_{\mathrm{KCl}}\right)$ acidity; the Kappen method for hydrolytic acidity (Y1); the EgnerRiehm Al method for readily available phosphorus (colourimetrically) and potassium (flamephotometrically). The values of the remaining properties were calculated.

\section{Results and discussions}

As shown by the obtained data (Table 1), the soil texture of the Ah horizon at the depth of $0-30 \mathrm{~cm}$ was characterised as light/coarse clay (according to the two-member classification based on the clay content, Dugalić and Gajić (2012)) with the dominance of physical clay fractions (53.15\%). The humus accumulative horizon was slightly skeletal, and a significant amount of gravel and sand fractions was present. The percentage of colloidal clay in the transitional AhE horizon was slightly smaller than in the humus accumulative horizon, while the silt content was increased, which affected water and air properties, but the horizon still belonged to coarse clays according to the classification.

The clay fraction increased (35.12\%) in the Bt horizon at the depth of $50-70 \mathrm{~cm}$, as previously determined by Đorđević et al. (2011). The content of colloidal clay was also high at the depth of 70-90 cm and the soil was classified into coarse clays. KapovićSolomun et al. (2015) tested the soil on serpentinites and determined that the humus accumulative horizon of leached soil was of a loamy texture, as was the eluvial horizon, while the illuvial horizon was of a somewhat heavier, loamy-clay texture, and contained a significant amount of serpentinite fragments. Knežević and Košanin (2006) pointed out that observed luvisols varied from silty clays to silty loams. 
Table 1.

Texture of leached soils

\begin{tabular}{|c|c|c|c|c|c|c|c|c|c|c|}
\hline \multirow{2}{*}{$\begin{array}{c}\text { Number } \\
\text { of } \\
\text { profiles }\end{array}$} & \multirow[b]{2}{*}{ Horizon } & \multirow[b]{2}{*}{$\begin{array}{l}\text { Depth } \\
\mathrm{cm}\end{array}$} & \multicolumn{7}{|c|}{ Mechanical fractions $\%$} & \multirow[b]{2}{*}{ Texture } \\
\hline & & & $\begin{array}{c}2-0.2 \\
\mathrm{~mm}\end{array}$ & $\begin{array}{c}0.2-0.05 \\
\mathrm{~mm}\end{array}$ & $\begin{array}{c}0.05-0.01 \\
\mathrm{~mm}\end{array}$ & $\begin{array}{c}0.01-0.005 \\
\mathrm{~mm}\end{array}$ & $\begin{array}{c}0.005-0.002 \\
\mathrm{~mm}\end{array}$ & $<0.002 \mathrm{~mm}$ & $<0.01 \mathrm{~mm}$ & \\
\hline \multirow{4}{*}{1} & $\mathrm{Ah}$ & $0-30$ & 8.39 & 13.40 & 25.05 & 11.52 & 12.39 & 29.25 & 53.15 & coarse clay \\
\hline & AhE & $30-50$ & 7.73 & 14.36 & 27.68 & 11.15 & 12.60 & 26.48 & 50.24 & coarse clay \\
\hline & $\mathrm{Bt}$ & $50-70$ & 5.01 & 11.51 & 25.69 & 11.50 & 11.17 & 35.12 & 57.79 & coarse clay \\
\hline & $\mathrm{Bt}$ & $70-90$ & 7.12 & 14.78 & 22.66 & 10.65 & 10.44 & 34.35 & 55.44 & coarse clay \\
\hline
\end{tabular}

The obtained data revealed that the porosity of the observed soil was very high at the depth of $0-30 \mathrm{~cm}$ (59.93\%; classification according to Pelišek (1964)), while it decreased with increasing depth, and it was moderate at the depths of $30-50 \mathrm{~cm}$ and $50-70 \mathrm{~cm}$.
Bulk density in the humus accumulative horizon was low and indicated that the soil texture was favourable, while it increased with increasing depth, and thus soil compaction was greater (Dugalić and Gajić, 2012), which was the case with the analysed leached soil.

Table 2.

Basic physical properties of analysed luvisol

\begin{tabular}{|c|c|c|c|c|c|c|c|c|c|c|}
\hline \multirow{2}{*}{$\begin{array}{c}\text { Number } \\
\text { of } \\
\text { profiles }\end{array}$} & \multirow{2}{*}{$\begin{array}{l}\text { Depth } \\
\mathrm{cm}\end{array}$} & \multicolumn{4}{|c|}{ Pore diameter, in $\mu \mathrm{m}$} & \multirow{2}{*}{$\begin{array}{c}\text { Total } \\
\text { porosity }\end{array}$} & \multirow{2}{*}{$\begin{array}{l}\text { Bulk density } \\
\mathrm{Mgm}^{-3}\end{array}$} & \multirow{2}{*}{$\begin{array}{l}\text { Specific } \\
\text { gravity } \\
\mathrm{Mgm}^{-3}\end{array}$} & \multirow{2}{*}{$\begin{array}{c}\text { Packing } \\
\text { density } \mathrm{Mgm}^{-3}\end{array}$} & \multirow{2}{*}{$\begin{array}{c}\text { Pore pressure } \\
\text { coefficient }\end{array}$} \\
\hline & & $>30$ & $30-10$ & $10-3$ & $<3$ & & & & & \\
\hline \multirow{3}{*}{1} & $0-30$ & 7.10 & 7.00 & 3.33 & 42.50 & 59.93 & 1.07 & 2.67 & 1.24 & 1.50 \\
\hline & $30-50$ & 6.83 & 4.80 & 3.27 & 36.22 & 51.12 & 1.31 & 2.68 & 1.55 & 1.05 \\
\hline & $50-70$ & 4.60 & 2.47 & 1.67 & 41.81 & 50.55 & 1.33 & 2.69 & 1.64 & 1.02 \\
\hline
\end{tabular}

With regard to the specific gravity of the tested soil (Table 2), there were more mineral particles than organic ones, and their values were practically equal throughout the depth. The packing density of particles depends on the clay content fraction and bulk density (Belić et al., 2014); in this study, packing density in the Ah horizon was lower than in the transitional $\mathrm{AhE}$ and $\mathrm{Bt}$ horizons, and therefore the soil was less compacted than in the other two horizons, in which the soil was moderately compacted. The pore pressure coefficient also indicated compaction/porosity, which confirms the fact that the soil in the humus accumulative horizon is loose, while the deeper horizons are somewhat denser.

The air capacity of the tested luvisol (Table 3) was good, very good and moderate in $\mathrm{Ah}, \mathrm{AhE}$ and $\mathrm{Bt}$ horizons, respectively, according to the British criteria, while it was high in $\mathrm{Ah}$ and AhE horizons, and low in the Bt horizon under the German criteria. In addition, the observed soil had very high water retention capacity at the depth of $0-70 \mathrm{~cm}(318 \mathrm{~mm})$ after the runoff of gravitational water. The values of wilting moisture confirmed that the given soil was predominately clayey due to its good ability to retain water. As calculated, the best retention and the highest availability of water were in the humus accumulative horizon, primarily due to the presence of humus (5.91\%, Table 4). With regard to filtration capacities, the obtained values were in the range of optimal, ecologically desirable values (Dugalić and Gajić, 2012).

Table 3.

Water and air properties of leached soil

\begin{tabular}{|c|c|c|c|c|c|c|c|c|c|c|}
\hline \multirow[t]{2}{*}{$\begin{array}{c}\text { Number of } \\
\text { profiles }\end{array}$} & \multirow[t]{2}{*}{ Horizon } & \multirow[t]{2}{*}{$\begin{array}{l}\text { Depth } \\
\text { cm }\end{array}$} & \multirow{2}{*}{$\begin{array}{c}\text { Air } \\
\text { capacity } \\
\%\end{array}$} & \multicolumn{2}{|c|}{$\begin{array}{c}\text { Water } \\
\text { retention } \\
\text { capacity }\end{array}$} & \multicolumn{2}{|c|}{$\begin{array}{l}\text { Wilting } \\
\text { moisture }\end{array}$} & \multicolumn{2}{|c|}{$\begin{array}{c}\text { Water } \\
\text { available to } \\
\text { plants }\end{array}$} & \multirow[t]{2}{*}{ Filtration, $\mathrm{cms}^{-1}$} \\
\hline & & & & $\%$ & $\mathrm{~mm}$ & $\%$ & $\mathrm{~mm}$ & $\%$ & $\mathrm{~mm}$ & \\
\hline \multirow{4}{*}{1} & $\mathrm{Ah}$ & $0-30$ & 14.10 & 49.27 & 148 & 29.26 & 88 & 20.01 & 60 & $2.90^{*} 10^{-4}$ \\
\hline & $\mathrm{AhE}$ & $30-50$ & 16.63 & 39.80 & 80 & 19.07 & 38 & 20.73 & 42 & $2.01 * 10^{-4}$ \\
\hline & $\mathrm{Bt}$ & $50-70$ & 7.07 & 45.17 & 90 & 23.65 & 47 & 21.52 & 43 & $1.85^{*} 10^{-4}$ \\
\hline & & $0-70$ & - & - & 318 & - & 173 & - & 145 & - \\
\hline
\end{tabular}

The observed physical traits of leached soil are very favourable for potato cultivation. A loose humus accumulative horizon with favourable water and air properties is characteristic of leached soils, as is the eluvial horizon, while the illuvial horizon with a somewhat more clayey faction is looser in comparison with typical leached soils.

Despite the favourable physical properties, the chemical properties of leached soils are somewhat less favourable (Table 4). The content of $\mathrm{P}_{2} \mathrm{O}_{5}$ (3.7 mg $100 \mathrm{~g}^{-1}$ in the Ah horizon) was low, which is a typical property of leached soil. Due to its poorer mobility in the soil, $\mathrm{P}_{2} \mathrm{O}_{5}$ was detected in minimum amounts at depths as low as 25-40 cm, while no amounts were detected at greater depths. Similar results were obtained by KapovićSolomun and Eremija (2017), who detected a somewhat higher content of organically bound $\mathrm{P}_{2} \mathrm{O}_{5}$ in the ochric horizon, while its content abruptly decreased at depths as low as $14-45 \mathrm{~cm}$, i.e. in the eluvial horizon. Leached soils were well supplied with available potassium $(22.6$ mg $100 \mathrm{~g}^{-1}$ soil at the depth of $0-25 \mathrm{~cm}$ ). Furthermore, a good supply of $\mathrm{K}_{2} \mathrm{O}$ was observed in the $\mathrm{Bt}$ horizon due to the presence of a larger amount of phyllosilicates clay minerals rich in $\mathrm{K}_{2} \mathrm{O}$.

In addition to $\mathrm{P}_{2} \mathrm{O}_{5}$, potato cultivation was limited by a slightly more acidic soil solution, where active acidity was highest in the humus accumulative horizon (pHн204.8), and gently decreased with increasing depth. 
Exchangeable acidity was rather constant throughout the soil depth and averaged 3.9. Hydrolytic acidity was very high $\left(47.35 \mathrm{~cm}^{3}\right)$, which indicated the necessity of basal liming/calcification. As reported by Gudžić et al. (2017), after the application of various rates of $\mathrm{CaO}$, hydrolytic acidity significantly decreased in proportion to the applied rate. The necessity of basal liming was indicated by the degree of saturation of the soil with adsorbed base cations in the Ah horizon that was moderately base unsaturated (31.31\%), and increasing depth resulted in an increased degree of base saturation due to the greater presence of phyllosilicates in relation to the plough layer.

Table 4.

Basic chemical properties of observed luvisol

\begin{tabular}{|c|c|c|c|c|c|c|c|c|c|c|}
\hline \multirow{2}{*}{$\begin{array}{c}\text { Depth, } \\
\text { cm }\end{array}$} & \multirow{2}{*}{$\begin{array}{l}\text { Hum } \\
\text { us \% }\end{array}$} & \multirow{2}{*}{$\begin{array}{c}\mathrm{Y} 1 \\
\mathrm{~cm}^{3}\end{array}$} & T-S & $S$ & $\mathrm{~T}$ & \multirow[b]{2}{*}{$\mathrm{V}, \%$} & \multicolumn{2}{|c|}{$\mathrm{pH}$} & $\mathrm{K}_{2} \mathrm{O}$ & $\mathrm{P}_{2} \mathrm{O}_{5}$ \\
\hline & & & \multicolumn{3}{|c|}{ meq $100 \mathrm{~g}^{-1}$} & & $\mathrm{H}_{2} \mathrm{O}$ & $\mathrm{KCl}$ & \multicolumn{2}{|c|}{ mg $100 \mathrm{~g}^{-1}$} \\
\hline $0-25$ & 5.91 & 47.35 & 30.78 & 14.03 & 44.81 & 31.31 & 4.8 & 3.9 & 22.6 & 3.7 \\
\hline $25-40$ & 1.82 & 27.76 & 18.04 & 14.37 & 32.41 & 44.35 & 5.1 & 4.1 & 12.1 & 0.1 \\
\hline $40-60$ & 0.81 & 24.51 & 15.93 & 19.52 & 35.45 & 55.06 & 5.3 & 4.0 & 22.0 & 0.0 \\
\hline $60-90$ & 0.51 & 29.02 & 29.02 & 22.08 & 40.94 & 53.93 & 5.3 & 3.9 & 23.3 & 0.0 \\
\hline
\end{tabular}

According to Dugalić and Gajić (2012), the cation exchange capacity (CEC or T) and values presented in Table 4 indicated that it was a clayey and poorly humus soil mainly consisting of phyllosilicates that did not have a high adsorption power, as previously determined by Kapović-Solomun and Eremija (2017). These values suggest that $\mathrm{Al}^{3+}$ and $\mathrm{Mn}^{2+}$ ions were present in the soil (Nduwumuremyi et al., 2013). If present at high concentrations, these ions can be phytotoxic. The sum of exchangeable bases (S) was correlated with the cation exchange capacity, and its values were slightly lower; therefore, taking into account all the determined values, the properties of the adsorptive soil complex were found to be favourable. The humus content in the Ah horizon was high (5.91\%), and abruptly decreased with increasing depth. These results showed that the chemical properties of the tested leached soil were somewhat less favourable for potato growing, but that potato can be grown successfully if proper agroameliorative practices, such as basal liming, manuring and NPK fertilisation, are used (Bošković-Rakočević et al. 2018).

\section{Conclusions}

Leached soils of Western Serbia are suitable for potato cultivation, because their agrophysical properties suit the growth of potato. On the other hand, agrochemical properties are unsatisfactory in some parameters (a low content of available phosphorus, high values of active, exchangeable and hydrolytic acidity), but their proper improvement can lead to high yields that approach the biological potential of potato. Potato can be cultivated on luvisol if proper amounts of complex NPK fertilisers with increased phosphorus and potassium levels are timely applied, coupled with basal liming treatments, manuring and the use of physiologically neutral nitrogen fertilisers.

\section{Acknowledgement}

This study was supported by the Serbian Ministry of Education, Science and Technological Development: Project 451/03/9/2021/14/200088 and 451-03$68 / 2020-14 / 200011$.

\section{References}

Belić, M., Nešić, Lj., Ćirić, V. (2014). Praktikum iz pedologije. Univerzitet u Novom Sadu, Poljoprivredni fakultet, Novi Sad, 1-90.

Bošković-Rakočević, Lj., Dinić, Z., Paunović, A., Bokan, N., Dugalić, M., Dugalić, G. (2018). Prinos i kvalitet krtola krompira u zavisnosti od đubrenja. Zbornik radova XXIII Savetovanja o biotehnologiji sa međunarodnim učešćem, Čačak, 9-10. mart 2018, 23, 18-23.

Bošković-Rakočević, Lj., Dinić, Z., Dugalić, G., Dugalić, M., Mladenović, J., Đurić, M. (2018). Effect of different rates and methods of application of NPK-fertilizers on the quality of potato tubers. Acta Agriculturae Serbica, 23(45), 101-110.

Driessen, P., Deckers, J., Nachtergaele, F. (2001). Mineral Soils conditioned by a (Sub)Humid Temperate Climate, Luvisols. Lecture notes on the major soils of the world, FAO.

Dugalić, G., Gajić, B. (2012). Pedologija. Univerzitet u Kragujevcu, Agronomski fakultet u Čačku, Čačak, 1-295.

Đorđević, A., Knežević, M., Tomić, Z., Golubović, S., Onjija, A., Životić, Lj.,Nikolić, N. (2011). Metodologija za sistematsko praćenje kvaliteta i stanja zemljišta u Republici Srbiji. Univerzitet u Beogradu, Poljoprivredni fakultet Zemun, 56-62.

Gudžić, N., Aksić, M., Gudžić, S., Jelić, M., Vuković, a. (2017). Efekat tri nivoa kalcifikacije na sadržaj mobilnog $\mathrm{Al} \mathrm{i}$ kiselost kod distrično smeđeg zemljišta. Zbornik radova XXII Savetovanja o biotehnologiji sa međunarodnim učešćem, Čačak, 10-11. mart 2017, 22, 93-99.

Kapović-Solomun, M., Eremija, S., Gavrić, Z. (2015). Karakteristike i ekološko-proizvodni potencijal zemljišta na serpentinitima u PJ „Donja Velika Usora". Glasnik Šumarskog fakulteta u Banjoj Luci, 23, 83-93.

Kapović-Solomun, M., Eremija, S. (2017). Zemljišta Javor planine. Univerzitet u Banjoj Luci, Šumarski fakultet Banja Luka, 167-199.

Knežević, M., Košanin, O. (2006). Karakteristike akričnog luvisola na krečnjacima Magleša. Glasnik Šumarskog fakulteta, Beograd, 93, 97-104.

Mcpharlin, I. (2014). Mid West potatoes: soil and fertiliser management. Agriculture and Food, Department of Primary Industries and Regional Development, https://www.agric.wa.gov.au/potatoes/mid-westpotatoes-soil-and-fertiliser-management?page $=0 \% 2 \mathrm{C} 1$.

Nduwumuremyi, A., Mugwe, J., Ruganzu, V. (2013). Effect on Soil Properties and Yield of Potato in Acidic Soil. Department of Natural Resource Management, Rwanda Agriculture Board (RAB), Rwanda, 20-23.

Tomić, Z., Rakonjac, Lj., Isajev, V. (2011). Izbor vrsta za pošumljavanje i melioracije $u$ centralnoj Srbiji. Monografija, Institut za šumarstvo, Beograd, 44-53. 